\title{
Article
}

\section{Analysis of fire deaths in Poland and influence of smoke toxicity}

Giebułtowicz, Joanna, Rużycka, Monika, Wroczyński, Piotr, Purser, David A and Stec, Anna A

Available at http://clok.uclan.ac.uk/18621/

Giebułtowicz, Joanna, Rużycka, Monika, Wroczyński, Piotr, Purser, David A and Stec, Anna A ORCID: 0000-0002-6861-0468 (2017) Analysis of fire deaths in Poland and influence of smoke toxicity. Forensic Science International, 277 . pp. 77-87. ISSN 0379-0738

It is advisable to refer to the publisher's version if you intend to cite from the work. http://dx.doi.org/10.1016/j.forsciint.2017.05.018

For more information about UCLan's research in this area go to http://www.uclan.ac.uk/researchgroups/ and search for <name of research Group>.

For information about Research generally at UCLan please go to http://www.uclan.ac.uk/research/

All outputs in CLoK are protected by Intellectual Property Rights law, including Copyright law. Copyright, IPR and Moral Rights for the works on this site are retained by the individual authors and/or other copyright owners. Terms and conditions for use of this material are defined in the policies page.

\section{CLoK}

Central Lancashire online Knowledge www.clok.uclan.ac.uk

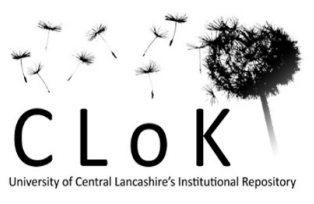


Published in: Forensic Science International, Volume 277, August 2017, Pages 77-87

\section{Analysis of Fire Deaths in Poland and Influence of Smoke Toxicity.}

Joanna Giebultowicz ${ }^{1}$, Monika Rużycka ${ }^{1}$, Piotr Wroczynski ${ }^{1}$, David A. Purser ${ }^{2}$, Anna A Stec $^{3}$

1. Department of Bioanalysis and Drugs Analysis, Warsaw Medical University, Poland

2. Hartford Environmental Research, Hatfield AL95DY, UK

3. Centre for Fire Hazards and Science, School of Physical Sciences and Computing, University of Central Lancashire, Preston, PR1 2HE, UK

\section{Corresponding Author:}

\section{Anna A Stec}

Centre for Fire Hazards and Science, School of Physical Sciences and Computing, University of Central Lancashire, Preston, PR1 2HE, UK

aastec@uclan.ac.uk

\section{Joanna Giebultowicz}

Department of Bioanalysis and Drugs Analysis, Warsaw Medical University, Poland joanna.giebultowicz@wum.edu.pl 


\title{
Analysis of Fire Deaths in Poland and Influence of Smoke Toxicity.
}

\begin{abstract}
Dwelling fires have changed over the years because the materials used in buildings and their contents have changed. They all contribute to an ever-growing diversity of chemical species found in fires, many of them highly toxic. While there is still a belief that carbon monoxide is the major lethal toxic agent in fires the changing nature of materials in interior finishes and furniture, and the increasing volume of synthetic materials containing nitrogen, capable of generating hydrogen cyanide, plus acid gases from halogen and phosphorus additives, is now a well-recognized cause of incapacitation, morbidity and mortality in domestic fires.
\end{abstract}

Data for the total number of 263 fire death cases in the Mazowieckie region (mainly Warsaw area) of Poland between 2003-2011 for dwellings fires were obtained from pathologists, forensic toxicologists, fire fighters and analysed. Factors contributing to the death such as the findings of the full post mortem examination (age, sex, health status, burns), the toxicological analysis (carbon monoxide, alcohol etc.), and a thorough investigation of the scene (fire conditions, fuel, etc.) were taken into account and are summarised.

\section{HIGHLIGHTS}

- Findings from 263 dwelling fire death cases over the period 2003-2011 in Mazowieckie region (mainly Warsaw area, Poland) have been reported.

- The majority of victims (around $60 \%$ ) were in the room of origin, of whom around half were found close to burned upholstered furniture.

- Fire deaths involved men (70\%) of whom 70\% had consumed alcohol, with an increased risk for those living alone. 
- By far the majority of victims ( $>65 \%$ ) had inhaled sufficient smoke, CO and other gases to cause incapacitation and $80 \%$ were reported as having soot in their airways.

- Approximately $60 \%$ had inhaled sufficient CO, smoke and other gases to have contributed to or been the main cause of death.

\section{KEYWORDS: fire, fire deaths, fire toxicity, carbon monoxide, burns, dwellings}

\section{INTRODUCTION}

Dwelling fires have changed over continuously since the 1950s because the materials used in buildings and their contents have changed. These changes contribute to an ever-growing diversity of chemical species found in fires, many of them highly toxic [1,2]. While there is still a belief that carbon monoxide is the major toxic agent responsible for deaths in fires, the changing nature of materials in interior finishes and furniture, with the increasing volume of synthetic materials containing nitrogen (capable of generating hydrogen cyanide) and halogen and phosphorus (capable of releasing acid gases organic environmental contaminants), are now well-recognized cause of incapacitation, morbidity and mortality in domestic fires $[3,4,5]$.

According to the UK fire statistics $[1,6]$ a progressive shift in the main cause of death from 'burns' to 'overcome by toxic gas or smoke' is clearly demonstrated for dwelling fires over the period from 1955 to the present. While the incidence of burns has remained stable, a very large rise in the fire toxicity deaths and injuries is demonstrated up to the late 1980s (Figure 1) and a much higher proportion suffering from toxic gas inhalation than burns is evident. In the UK, since the introduction of the furniture flammability regulations in 1988, and the increasing use of domestic smoke alarms in the early 1990s, there has been a progressive decline in fire deaths and injuries [7]. However, in many parts of Europe fire deaths and injuries are still rising. For 
example, recent Polish fire deaths and injuries show more than twice the UK's number of fatalities per head of population [8], with a higher and increasing incidence of injuries. This demonstrates that the problems associated with fire effluent toxicity have not gone away, and are becoming more important as the proportion of smoke deaths increases. Figure 1 includes total deaths and injuries data for both Poland as a whole and for the Mazowieckie region, for which a more detailed analysis has been made (particularly for the Warsaw area). This confirms that the total injury and death statistics for this region are similar to those for Poland in general. 


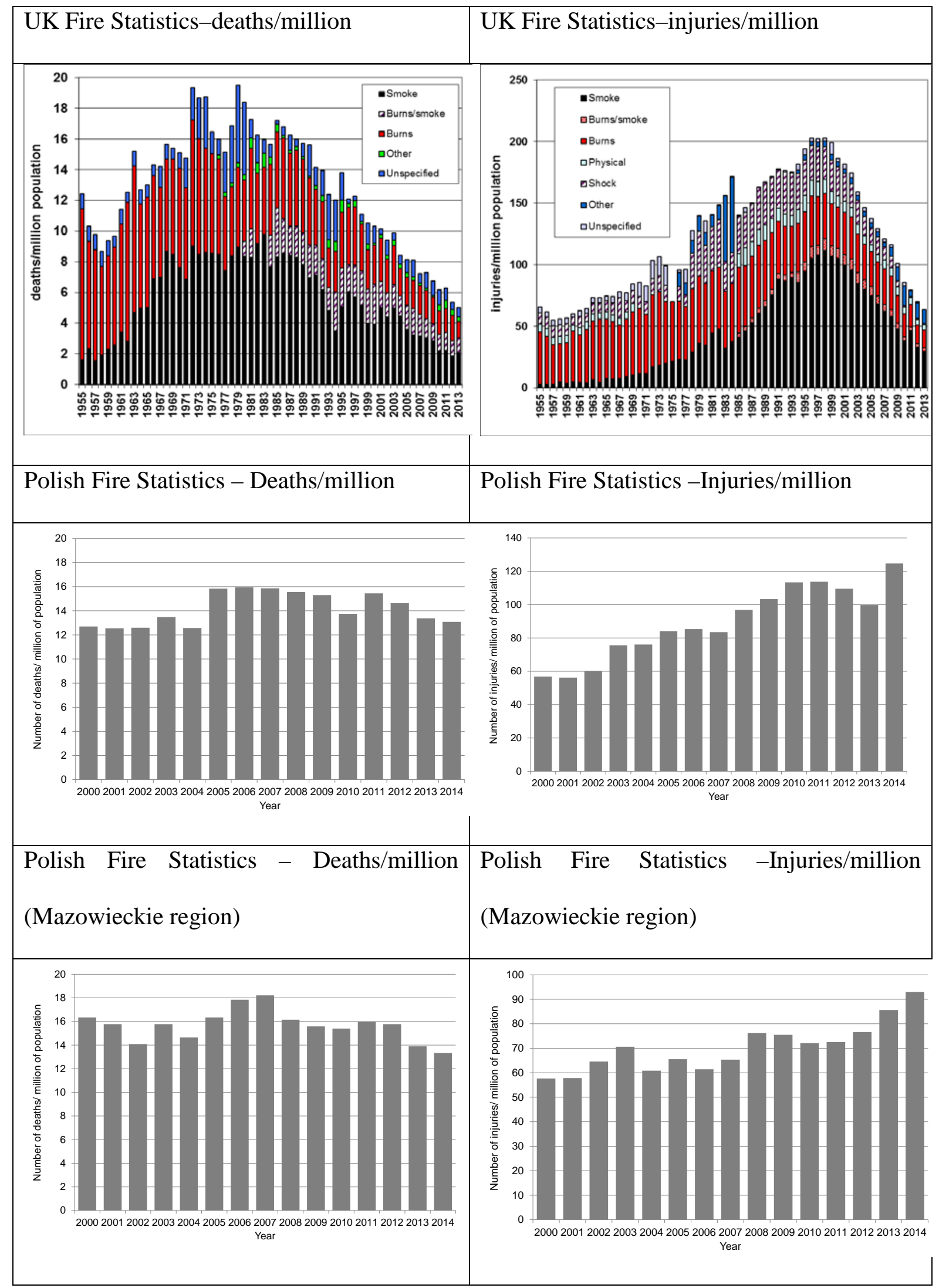

Figure 1 Comparison of the number of fire deaths and injuries in UK and Poland 


\section{FIRE SCENARIOS AND FUELS}

A large percentage of fire deaths occur in dwellings (80\%) [6]. The majority of fatal casualties are found in the room of origin of the fire, often close to an exit, where they become incapacitated during attempts to escape [3,9,10], but a large proportion (approximately 30$40 \%$ ) of casualties occur in locations beyond the room of fire origin [11]. These fires are mostly confined to living rooms or bedrooms with upholstery or bedding being the items first ignited, but the toxic smoke often spreads rapidly beyond the room of origin and throughout the dwelling. Once the flaming starts, untenable conditions can develop rapidly, both in the fire room and beyond, often within a few minutes [3,12]. In the room of fire origin the smoke, irritants and heat rapidly impairs escape efficiency, then collapse and syncope (fainting) occur due to the effects of asphyxiant gases ( $\mathrm{CO}$ and $\mathrm{HCN}$ ) or heat. Occupants may be able to escape if they voluntarily drop on the floor to crawl out, but even if the fire remains localised, smoke and toxic gases may spread far beyond the original source of the fire, causing dangerous conditions resulting and rapid incapacitation beyond the room of origin. Up to flashover, fire itself is contained in the room of origin; in post flashover conditions the fire is extended beyond the room of origin, and the generation and spread of fire effluents is greatly increased.

Fire toxicity is both scenario and material dependent $[13,14]$. Burning behaviour and particularly toxic product yields depend most strongly on a few key factors: material composition, fuel-air equivalence ratio, temperature and oxygen concentration are generally the most important $[11,12]$. It is now recognized that compared with natural materials, many synthetic polymeric materials ("plastics”) generate more heat more swiftly, spread flames faster, generate larger amounts of denser visible smoke and toxic gases, resulting in higher concentrations of toxic thermal decomposition products $[15,16]$. This has resulted in the need 
to apply flame retardant treatments in an attempt to reduce flammability. The treatments involve substances producing additional toxic gases during combustion (such as combustion products containing halogens, nitrogen and phosphorus) and also increase the yields of common combustion products, including CO, HCN and organic irritants [17]. Therefore the importance of determining the yields and concentrations of toxic gases produced from different materials thermally decomposed under various fire conditions is evident [18]. Common components of smoke generated from different fuels and their effects on human are presented in Table 1.

\begin{tabular}{|c|c|c|}
\hline Toxic products & Fuel & Effects \\
\hline \multicolumn{3}{|l|}{ Physical agent } \\
\hline Heat/Flame & Flaming combustion & Burns, Laryngotracheitis \\
\hline Oxygen depletion $\left(\mathrm{O}_{2}\right)$ & Combustion/Pyrolysis & Asphyxia \\
\hline \multicolumn{3}{|l|}{ Chemical agent } \\
\hline $\begin{array}{l}\text { Carbon monoxide } \\
\text { (CO) }\end{array}$ & $\begin{array}{l}\text { Incomplete combustion of any } \\
\text { organic material }\end{array}$ & $\begin{array}{l}\text { Functional asphyxia, narcosis } \\
\text { tissue hypoxia, syncope, organ } \\
\text { failure, death }\end{array}$ \\
\hline $\begin{array}{l}\text { Hydrogen Cyanide } \\
(\mathrm{HCN})\end{array}$ & $\begin{array}{l}\text { Paper, Silk, Wool, Polyurethane, } \\
\text { Polyamide, Acrylics, some } \\
\text { synthetic rubbers (elastomers), }\end{array}$ & $\begin{array}{l}\text { Cellular Asphyxia, tissue } \\
\text { hypoxia, syncope, organ } \\
\text { failure, death }\end{array}$ \\
\hline Carbon dioxide $\left(\mathrm{CO}_{2}\right)$ & $\begin{array}{l}\text { Complete combustion of any } \\
\text { organic material }\end{array}$ & $\begin{array}{l}\text { Simple asphyxia, distress, } \\
\text { narcosis, syncope, Increased } \\
\text { respiratory drive }\end{array}$ \\
\hline $\begin{array}{l}\text { Halogenated acids } \\
(\mathrm{HCl}, \mathrm{HBr}, \mathrm{HF})\end{array}$ & $\begin{array}{l}\text { Vinyl(Polyvinyl Chloride), } \\
\text { materials treated with halogenated } \\
\text { flame retardants }\end{array}$ & $\begin{array}{l}\text { Eye and respiratory tract } \\
\text { irritation, escape impairment, } \\
\text { incapacitation, necrosing }\end{array}$ \\
\hline
\end{tabular}




\begin{tabular}{|l|l|l|}
\hline & & airway mucosa, pulmonary \\
& oedema and inflammation \\
\hline
\end{tabular}

Table 1 Common components of smoke and their effect on human

\section{TOXIC AND PHYSICAL HAZARDS IN FIRES}

The physiological effects of exposure to toxic smoke in fires may lead to death or permanent injury $[3,19]$. This arises partly from the direct toxicity of combustion gases and partly from the incapacitating effects of exposure, which impair or prevent escape so that victims remain in the fire until exposure to heat or toxicity results in injury or death. The initial effects on escape capability result from impaired vision due to the optical opacity of smoke and the painful effects of irritant smoke products (nitrogen oxides, hydrogen chloride, hydrogen bromide etc.) on the eyes and respiratory tract, with pain and breathing difficulties. This is followed by confusion and loss of consciousness due to the asphyxiant effects of carbon monoxide and hydrogen cyanide. Victims then die within a few minutes from cardiorespiratory failure, or if rescued alive at the fire scene may suffer permanent injury or death due to neurological damage from asphyxiants or respiritatory tract injury, involving treachobronchitis, lung inflammation and oedema, often followed by pneumonia, from the inhalation or irritant smoke or from burns [2,3,4,5].

\section{$\underline{\text { Asphyxiants }}$}

Carbon monoxide binds to the haemoglobin in red blood cells resulting in the formation of carboxyhaemoglobin (COHb), with stability constant 200 times greater than that of oxyhaemoglobin, impairing the transport and delivery of oxygen from lungs to the body resulting in reduced blood oxygen capacity and tissue oxygen availability. This causes deterioration in mental and muscular performance. $\mathrm{CO}$ also combines with myoglobin in the 
muscle cells, impairing diffusion of oxygen to cardiac and skeletal muscles. COHb levels in the blood have been reported to cause different physiological effects dependent on the concentration detected. Levels greater than $10 \%$ induce clinical symptoms and higher than $50 \%$ are considered to be lethal $[20,21]$. Since most inhaled CO remains in the blood the \%COHb concentration is a good measure of the total dose inhaled and a good indicator of the effects on exposed subjects. The inhaled CO dose depends mainly on the inhaled CO concentration, the respiration (and hence activity level) of the subject and the exposure time [21]. A more detailed physiological response and its corresponding effects are given in Table 2 which shows effects at different \% $\mathrm{COHb}$ levels and the inhaled $\mathrm{CO}$ concentrations required to achieve them within approximately one hour for a resting subject or 30 minutes for an active subject (for example walking to escape from a fire). When subjects inhale CO in a fire, collapse with syncope occurs at around $30 \% \mathrm{COHb}$ in active subjects or $40 \% \mathrm{COHb}$ in resting subjects. If rescued with up to $50 \% \mathrm{COHb}$ and treated with oxygen at the scene, subjects have a good probability of recovery, but a very low survival rate above this limit. If they remain in the fire, CO uptake continues while comatose, until respiration and circulation cease, and death occurs, from which point the $\% \mathrm{COHb}$ level remains constant. The levels found in non-burned fatalities range from $<30$ up to $90 \% \mathrm{COHb}$, with a mode of $70-80 \% \mathrm{COHb}$, but the proportions of fatalities found with lower \%COHb levels in the $30-60 \% \mathrm{COHb}$ range is higher in non-burned fire victims than in victims of $\mathrm{CO}$ poisoning [2].

\begin{tabular}{|l|l|l|}
\hline $\begin{array}{l}\text { CO } \\
\text { concentrations } \\
\text { (ppm) }\end{array}$ & $\begin{array}{l}\text { COHb\% after 1 } \\
\text { hour resting or 30 } \\
\text { minutes walking }\end{array}$ & \\
\hline & $\begin{array}{l}<1.5 \% \text { non-smoker } \\
>1.5-5 \% \text { smokers }\end{array}$ & $\begin{array}{l}\text { Normal levels } \\
\text { No symptoms }\end{array}$ \\
\hline 50 & $\begin{array}{l}3-6 \% \text { (equilibrium } \\
\text { \% after several } \\
\text { hours) }\end{array}$ & $\begin{array}{l}\text { Threshold limit value } \\
\text { Slightly decreased ability to exercise (5-7\%) }\end{array}$ \\
\hline $180-400$ & $5-10 \%$ & $\begin{array}{l}\text { Exercise tolerance reduced, visual light threshold } \\
\text { increased, less exercise required to induce chest } \\
\text { pains in angina patients }\end{array}$ \\
\hline
\end{tabular}




\begin{tabular}{|c|c|c|}
\hline $400-800$ & $10-20 \%$ & $\begin{array}{l}\text { Concentrations which can be inhaled for } 1 \\
\text { hour without serious effects in normal resting } \\
\text { subjects. } \\
\text { Diminution of visual perception, manual dexterity } \\
\text { and performance. Headache and dilation of } \\
\text { cutaneous blood vessels, abnormal visual evoked } \\
\text { response, may be lethal for subjects with } \\
\text { compromised cardiac function. }\end{array}$ \\
\hline $800-1200$ & $20-30 \%$ & $\begin{array}{l}\text { Concentrations causing unpleasant symptoms, } \\
\text { potentially dangerous after an hour, with risk } \\
\text { of collapse on exercise } \\
\text { Headache with throbbing in temples, easily } \\
\text { fatigued and possible dizziness, flu-like } \\
\text { symptoms, syncope }\end{array}$ \\
\hline $1200-1600$ & $30-40 \%$ & $\begin{array}{l}\text { Concentrations that can be incapacitating and } \\
\text { even fatal within an hour in resting subjects } \\
\text { Severe headache, weakness, dizziness, confusion, } \\
\text { vision disturbances, arrhythmia, nausea, } \\
\text { vomiting, collapse and syncope, coma }\end{array}$ \\
\hline $1600-2000$ & $40-50 \%$ & $\begin{array}{l}50 \% \text { COHb limit for post-exposure recovery } \\
\text { with treatment in most subjects, } \\
\text { Above } 40 \% \text { COHb most subjects comatose but } \\
\text { continue to inhale CO so that uptake continues } \\
\text { until respiration and circulation cease. } \\
\text { Concentrations incapacitating to fatal within an } \\
\text { hour. Slow heart rate and arrhythmias may occur. } \\
\text { Symptoms same as above but more severe, coma, } \\
\text { and decreasing respiration } \\
\text { COHb levels in } 7 \% \text { of CO poisoning fatalities at. }\end{array}$ \\
\hline $2000-3000$ & $50-60 \%$ & $\begin{array}{l}\text { 60\% COHb approximate } 5 \% \text { survival rate if } \\
\text { treated, fatal if untreated } \\
\text { Increased respiratory rate and pulse, intermittent } \\
\text { convulsions, then coma and slow Cheyne-stokes } \\
\text { respiration, leading to apnoea and death. } \\
\text { Recovery and survival unlikely even with } \\
\text { treatment. Intermittent convulsions, coma, } \\
\text { depressed heartbeat and respiratory rate, lethal. } \\
\text { COHb levels in } 11 \% \text { of CO poisoning fatalities }\end{array}$ \\
\hline $3000-4000$ & $60-70 \%$ & $\mathrm{COHb}$ levels in $23 \%$ of $\mathrm{CO}$ poisoning fatalities. \\
\hline $4000-6000$ & $70-80 \%$ & $\begin{array}{l}\text { Mode of \%COHb distribution in CO poisoning } \\
\text { fatalities }-29 \% \text { of CO poisoning fatalities }\end{array}$ \\
\hline $6000-8000$ & $80-90 \%$ & $\mathrm{COHb}$ levels in $21 \%$ of $\mathrm{CO}$ poisoning fatalities. \\
\hline$>8000$ & $>90 \%$ & $\begin{array}{l}\text { Upper limit of \%COHb distribution in fatalities, } \\
\text { in } 2 \% \text { of } \mathrm{CO} \text { poisoning fatalities }\end{array}$ \\
\hline
\end{tabular}

Table 2 Carbon monoxide concentrations and the resulting physiological response and blood COHb\% levels [3,20,21]. 
Data relating symptoms in humans to various concentrations of hydrogen cyanide (HCN) are very limited as time to incapacitation by hydrogen cyanide depends partly on rate of uptake and partly on dose $[3,19,21,22]$. HCN is approximately 25 times more toxic than carbon monoxide, and very rapidly acting toxicant [23]. Following inhalation, hydrogen cyanide is absorbed into the blood, due to the cyanide ion, which is formed by hydrolysis in the blood. Unlike CO, which remains primarily in the blood, cyanide ion is distributed throughout the body water and is in contact with the cells of tissues and organs [23,21]. At low concentrations 93-99\% of total cyanide in the blood is found in erythrocytes bound to methaemoglobin (MetHb), deoxygenated, form of haemoglobin which has a very high affinity for cyanide and forms cyanomethaemoglobin. With increasing amounts of cyanide in the blood a larger amount is found in the plasma $[21,24]$. In the tissues, cyanide binds to haem groups on the enzyme cytochrome oxidase at the mitochondrial level, reducing mitochondrial oxygen utilization and cellular respiration resulting in lactic acidosis and leading to loss of cellular functions (cellular hypoxia and acidosis), then to cell death $[24,25]$. Effects are more harmful in tissues which have high ATP and oxygen requirements. Additionally there is a stimulation of respiratory frequency (tachypnea), due to the body's regulating chemoreceptor cells responding to a need for oxygen, immediately followed by severe depression lasting until convulsions, respiratory arrest and death. Although cardiac irregularities are often noted in HCN intoxication, the heart invariably outlasts respiration and death is usually due to respiratory arrest of central nervous system origin [26].This mechanism causes a more rapid uptake of not only HCN, but also other toxicants which may be present $[21,24,27,28,29]$. Due to the physiology of uptake and toxicology of inhaled HCN, incapacitation (loss of consciousness and coma) occurs within a few minutes of exposure to concentrations above 200 ppm, but requires 30 minutes or more below 100 ppm. Since concentrations of 500-1000 ppm HCN commonly occur during the first 
few minutes of domestic fires involving upholstered furniture and bedding, it is considered to be an important cause of early incapacitation before inhaled COHb levels are significant $[3,19,21]$.

\section{$\underline{\text { Irritants }}$}

In contrast to the direct effects of asphyxiant toxicants, the effects of exposure to irritants (hydrogen bormide, hydrogen chloride) are more varied. Irritant gases such as hydrogen chloride ( $\mathrm{HCl})$, hydrogen bromide $(\mathrm{HBr})$ produce signs and symptoms of both sensory and upper respiratory tract irritation, and of pulmonary irritation. Depending upon the concentration of an irritant and the duration of exposure (i.e. the dose) sensory/upper respiratory tract irritation stimulates the trigeminal and vagus nerve receptors in the eyes, nose, throat and upper respiratory tract causing discomfort, then severe pain. The effects may include tears and reflex blinking of the eyes, pain in the nose, throat and chest, breath-holding and coughing. This result in immediate incapacitation, mainly due to the effects on the eyes and upper respiratory tract. At sufficiently high concentrations, most irritants can penetrate deeper into the lungs, causing pulmonary irritation effects which may cause post-exposure respiratory distress and death, due to pulmonary oedema, and longer term damage deeper in the lung $[3,12]$, which generally occurs from a few hours up to several days after exposure,.

\section{$\underline{\text { Smoke }}$}

As smoke accumulates in an enclosure, it becomes increasingly difficult for occupants to find their way out. This has a significant effect on the time required for escape. Moreover, at some degree of smoke intensity, occupants can no longer discern boundaries and become unaware of their location relative to doors, walls, and windows, even if they are familiar with the 
premises. When this occurs, occupants can become so disoriented that they are unable to find their way out $[3,12]$.

\section{COMPILATION AND ANALYSIS OF DATA FROM PATHOLOGICAL, FIRE INVESTIGATORS AND FIRE FIGHTERS FINDINGS}

These studies aimed to answer the following questions:

- What fuels are likely to produce the lethal conditions that led to death?

- The extent to which fire deaths can be attributed to burns or toxic gases and the distribution of \%COHb levels in fire fatalities

- If the relative role of other toxicants than CO cause fire fatalities, and critical COHb values representing lethality (Is there any evidence for a contribution to lethality from toxicants in fire victims other than carbon monoxide)?

- Which types of fires account for most fire deaths due to smoke inhalation?

Data for the total number of 263 fire death cases within 2003-2011 for dwellings fires were obtained and analysed from pathologists, forensic toxicologists, and fire fighters. Factors contributing to death such as the findings of the full post mortem examination (age, sex, burns, health condition), the toxicological analysis (carbon monoxide, alcohol), and a thorough investigation of the scene (fire conditions, fuel, etc.) were taken into account and are summarised.

\section{RESULTS OF FATAL FIRE DATA ANALYSIS}

The total number of 263 fire death cases is split by each year and is presented in Table 3.

\begin{tabular}{|c|c|c|c|}
\hline Total number of cases & Year & Number & $\mathbf{\%}$ \\
\hline & 2003 & 26 & $10 \%$ \\
\hline
\end{tabular}




\begin{tabular}{|c|c|c|c|}
\hline \multirow{3}{*}{$\mathbf{2 6 3}$} & 2004 & 23 & $9 \%$ \\
\cline { 2 - 4 } & 2005 & 31 & $12 \%$ \\
\cline { 2 - 4 } & 2006 & 36 & $14 \%$ \\
\cline { 2 - 4 } & 2007 & 33 & $13 \%$ \\
\cline { 2 - 4 } & 2008 & 32 & $12 \%$ \\
\cline { 2 - 4 } & 2009 & 28 & $11 \%$ \\
\cline { 2 - 4 } & 2010 & 27 & $10 \%$ \\
\hline & 2011 & 27 & $10 \%$ \\
\hline
\end{tabular}

Table 3 Number of fire death cases investigated for 2003-2011.

Figure 2 presents the location of the dwelling fires, as well as the causes. The majority of the fires are reported as accidental incidents (approximately 70-80\%) and occurred in the brickmade houses. Up to $50 \%$ of investigated fires were caused by carelessness (which includes any fire involving direct action by an occupant, such as activities involving flaming sources (such as candles or cooking fires), $10-20 \%$ by the electrical failure and cigarettes. In some cases (up to $30 \%$ ) the cause is unknown.

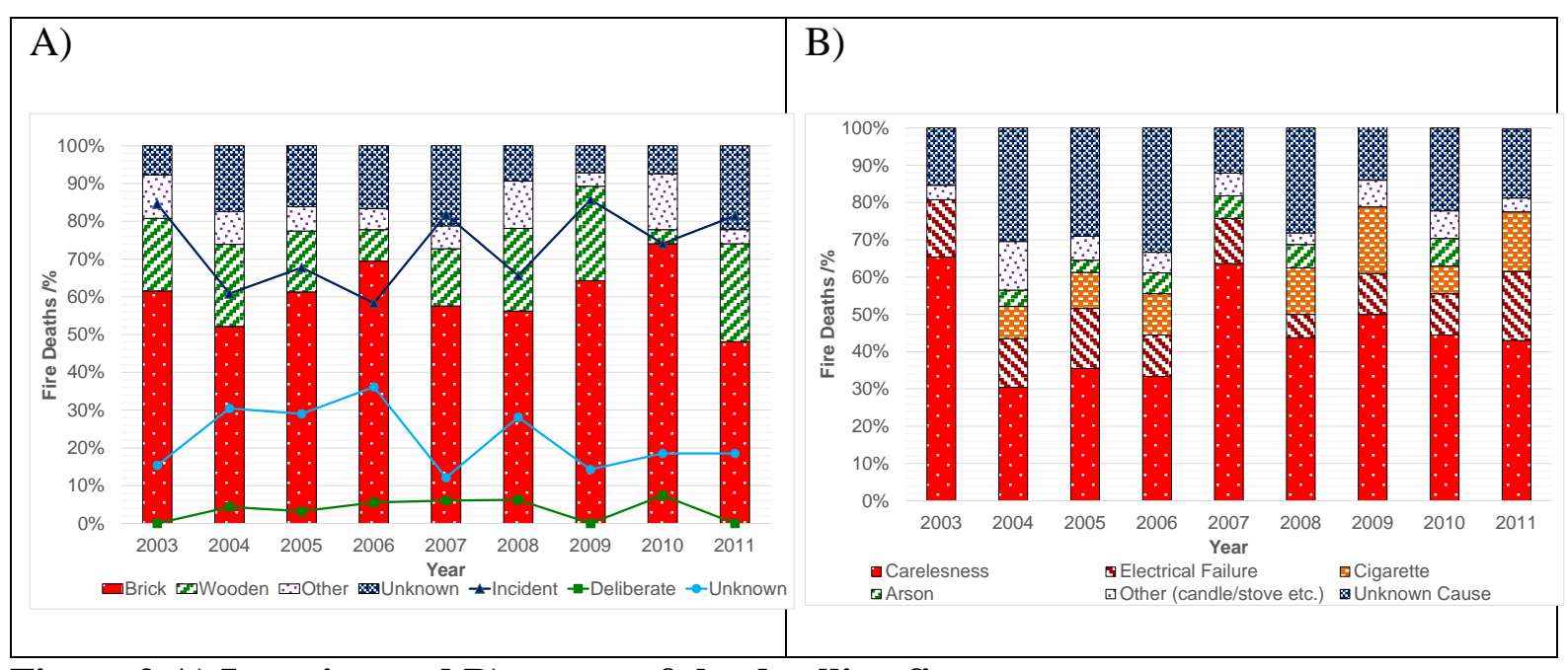

Figure 2 A) Location and B) causes of the dwelling fires. 
Figure 3 presents location of the fire victims. Approximately $90 \%$ of the fire deaths were identified at the fire scene. Up to $60 \%$ were identified in the room where the fire started (for 2010 up to $80 \%$ ). Of these, approximately $25 \%$ of fire victims were found close to different types of the upholstered furniture (armchair, sofa, bed etc.), which involved nitrogencontaining fuels that are a source for gases other than carbon monoxide, such as hydrogen cyanide. However the actual numbers are likely to have been somewhat higher, since $10-20 \%$ of the cases did not have reported locations. Another consideration is that approximately $20 \%$ of fatalities were reported as “outside the house”. This group includes those who died outside the building because they either escaped or were rescued alive, but then died. In addition, a proportion were found beyond in the building but beyond the room of fire origin, but this category is not identified in the records.

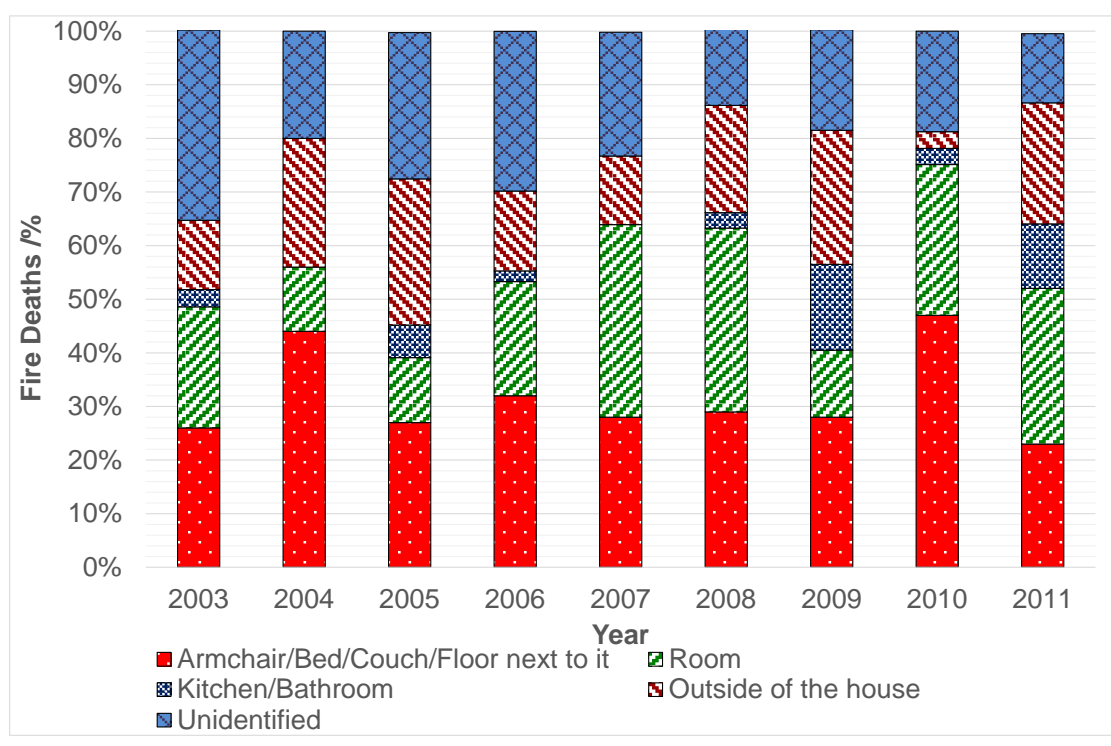

\section{Figure 3 Location of the fire victims.}

Figure 4 presents gender and lifestyle of identified fire victims. Approximately $70 \%$ of fatalities were male and $20 \%$ female. In terms of the lifestyle, the proportions living alone and those living in families were approximately equal, although the status is unknown for approximately $30 \%$ of cases. Since the proportion of single person households in Poland is 
only around 9\%, the fire data therefore indicate a considerably greater fire death risk for persons living alone.

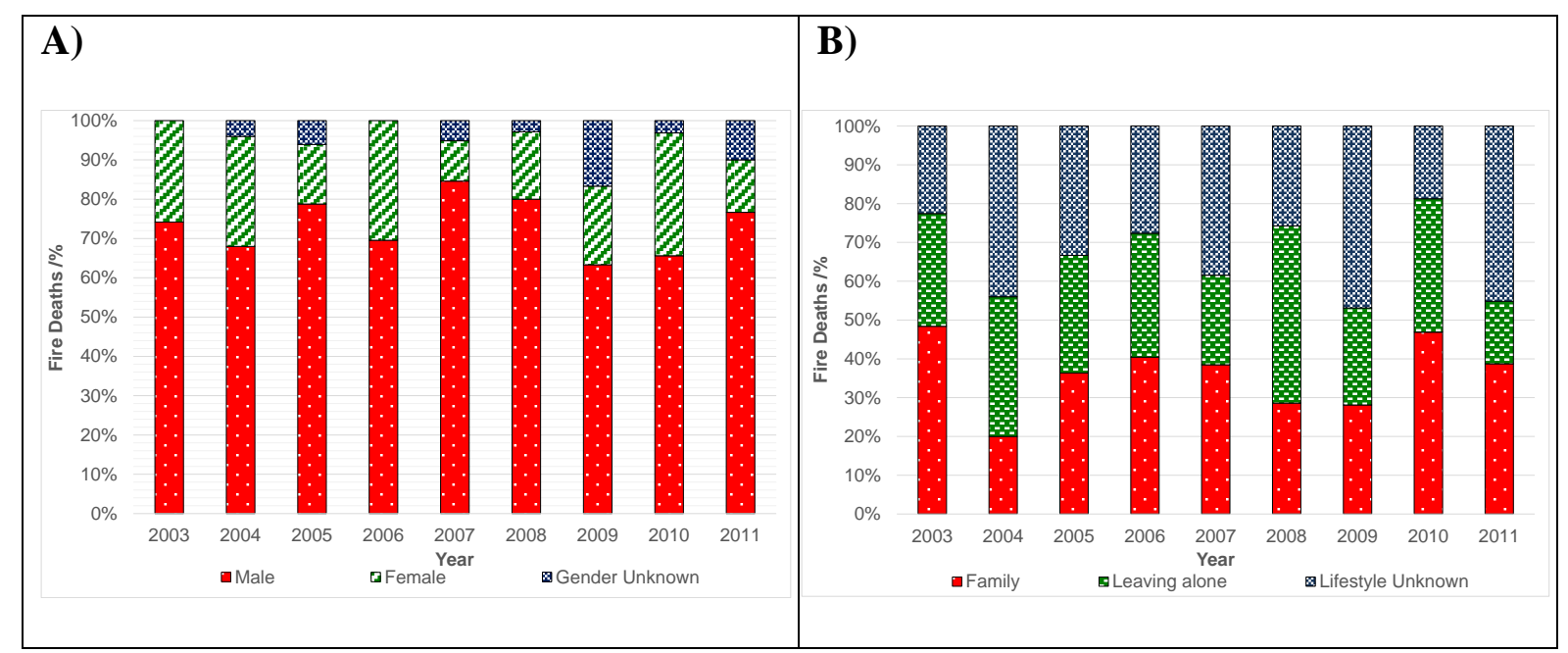

Figure 4 Fire deaths: A) gender and B) lifestyle.

Figure 5 presents the age of the fire victims. The majority of people who died were in the range between 20-70 years. This somehow contradicts a general belief that the most people who are dying in fires are either very young or elderly. As proportions of the population, the fire death risk was approximately similar for the 30-50, 50-70 and 70+ age groups, while somewhat lower for those under 20 years. Additionally, approximately $70 \%$ of the fire victims had consumed alcohol. 


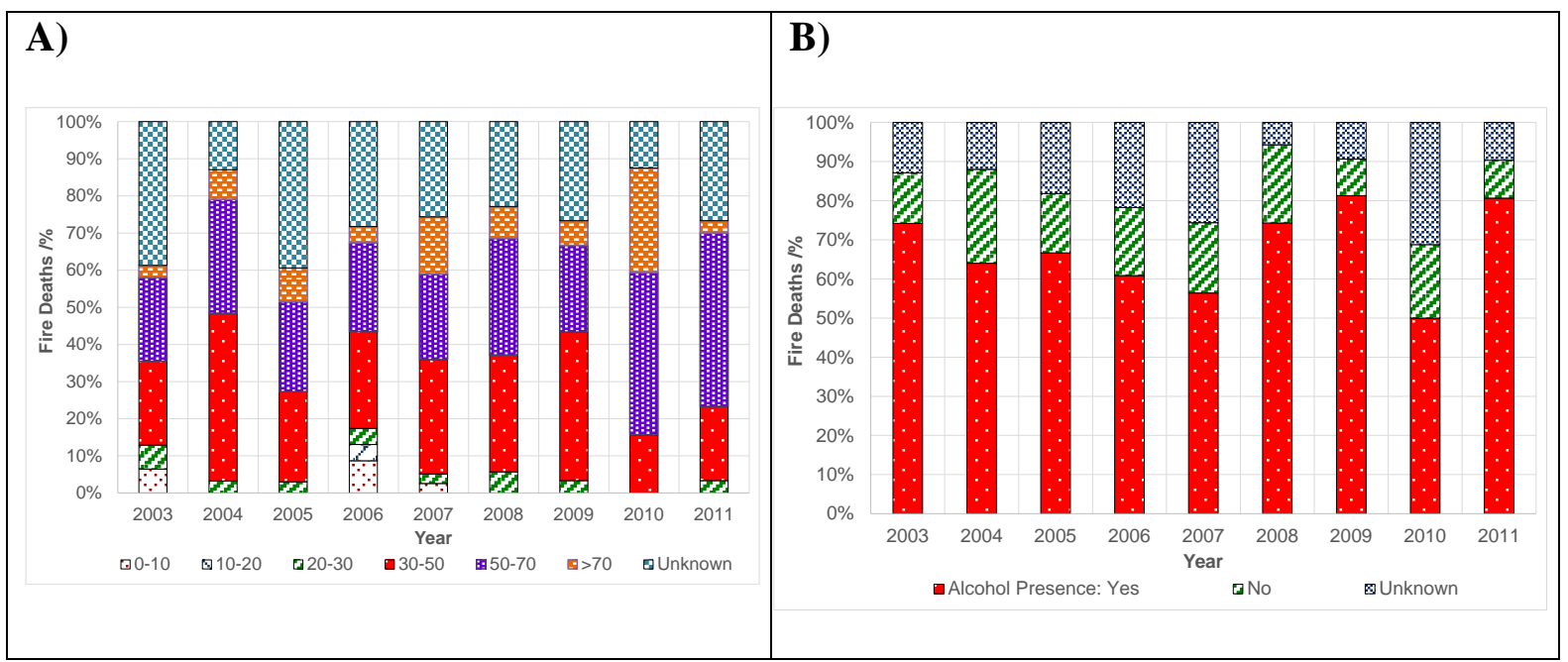

Figure 5 Fire deaths: A) age and B) presence of the alcohol.

Figure 6 summarises the incidence and severity of smoke inhalation. Since all fire gases are present simultaneously in fire effluent the dose of $\mathrm{CO}$ taken up in the form of \%COHb provides a measure not just of the $\mathrm{CO}$ uptake but also that of other toxic gases and smoke particulates present in the fire effluent. Taking $40 \% \mathrm{COHb}$ as the approximate threshold for death due to inhalation of $\mathrm{CO}$ and other toxic effluents, Figure $6 \mathrm{a}$ indicates that approximately $50 \%$ of fatalities had inhaled lethal doses of toxic gases, while Figure 6b shows that approximately $80 \%$ had soot in their airways, confirming that they were alive for some time during the fire and had inhaled significant quantities of smoke particulates.

Based on values from Table 2, whereby only a small proportion of CO poisoning fatalities have \%COHb levels below $60 \% \mathrm{COHb}$. Figure 6 shows that the majority of fatalities in these fires died from causes other than CO inhalation. The included burns and/or the effects of other gases. 


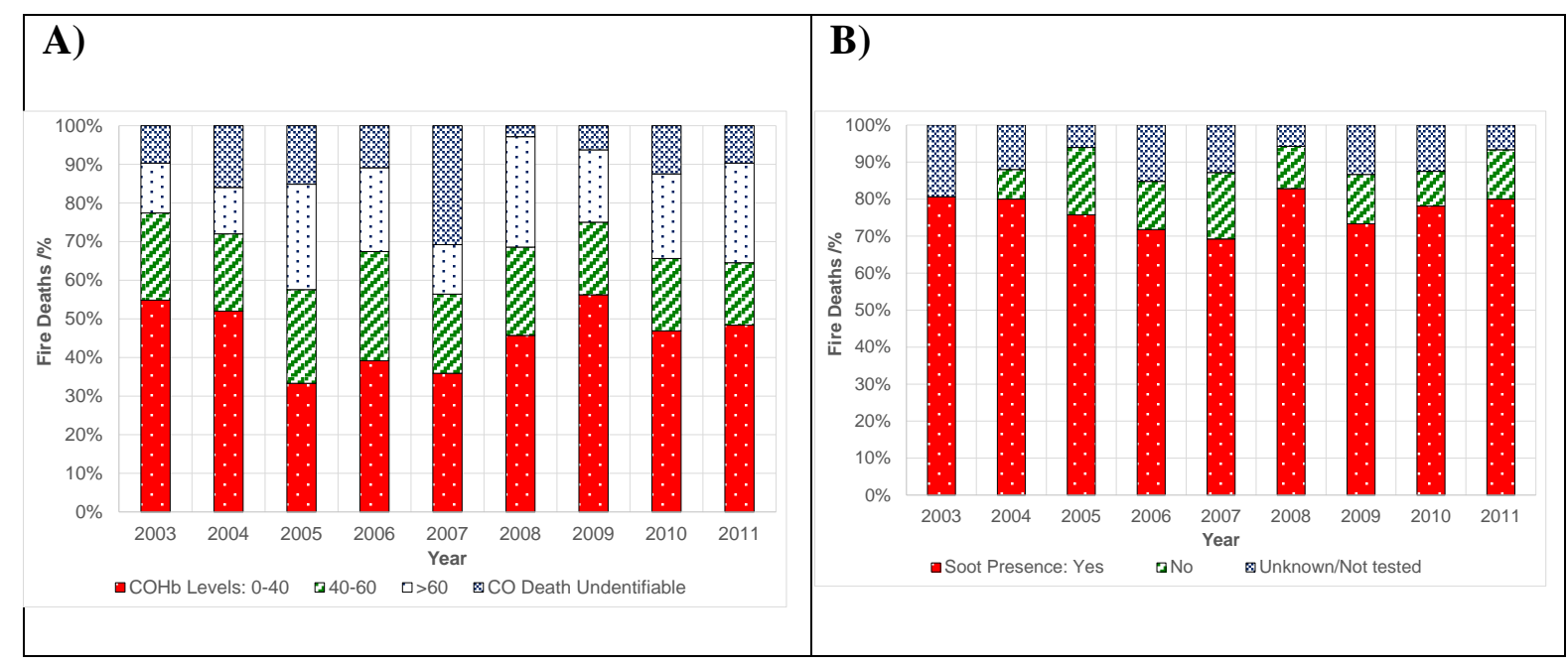

Figure 6 Fire deaths: A) COHb levels B) presence of the soot in the airways.

Figure 7 shows a more detailed breakdown of the distribution of \%COHb levels and burns for 247 fatalities over the 2003-2011 period. Burns have been classified into severe, lifethreatening burns or minor burns in terms of recorded burn severity and body area burned.

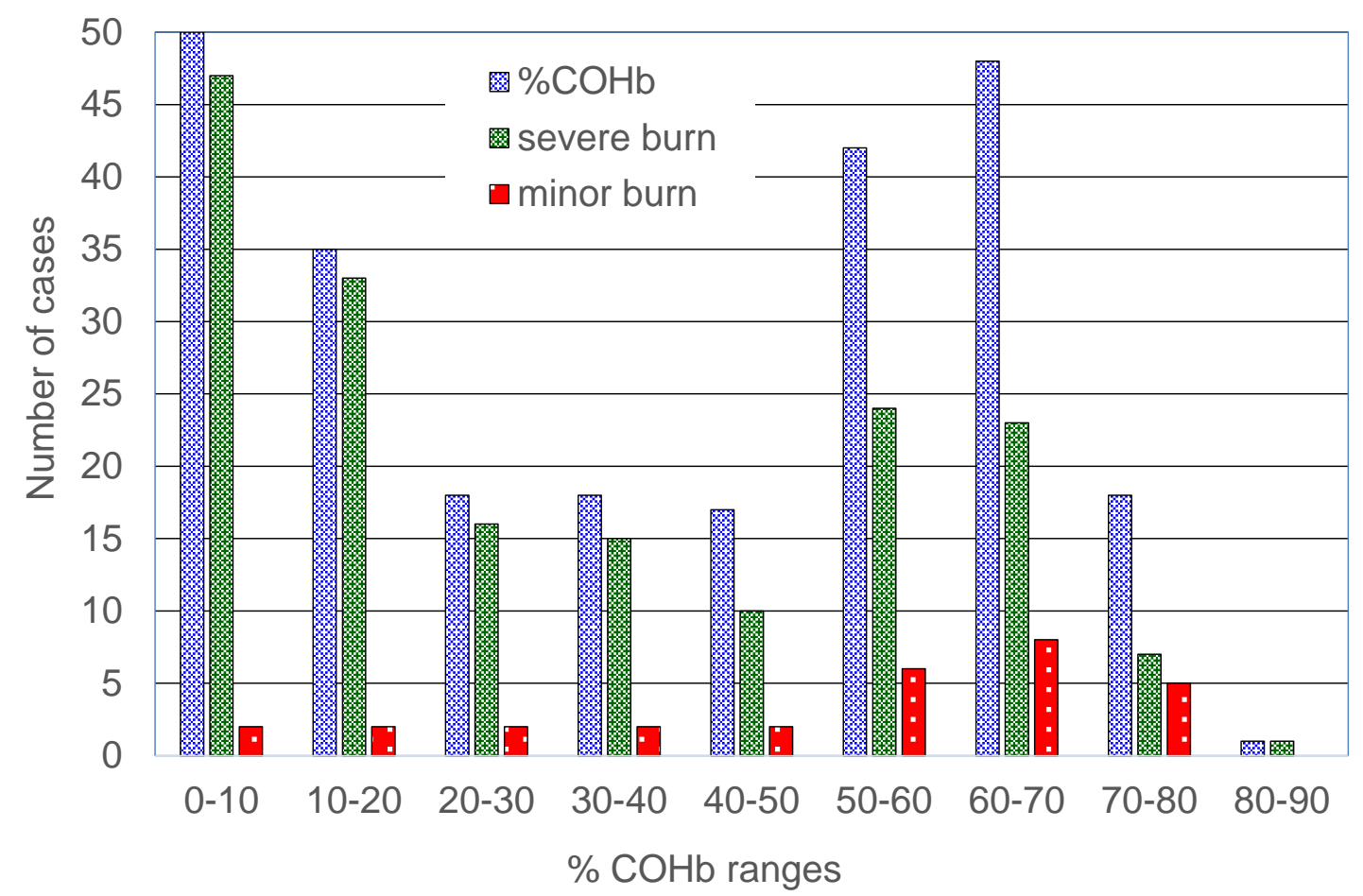

Figure 7 Fire deaths: Frequency distribution of \%COHb levels and incidence of severe (lifethreatening) or minor burns. 
Since CO is present in all fires, and is inhaled continuously during a fire, the \%COHb level in a fatality provides an indication of the exposure duration during the fire before the victim died. While the burn severity provides an indication of whether or not death may have been due to burns, since there is no distinction between pre- and post-mortem burns it is not possible to determine at what stage during exposure the burns occurred. Taking the incidence and severity of burns together with the \% $\mathrm{COHb}$ data, and other signs such as soot deposition and burns to the respiratory tract, it is possible to establish some aspects of the likely exposure history.

The results show that up to approximately $40 \% \mathrm{COHb}$, almost all fatalities are recorded as having suffered severe (mostly category 4 - full-thickness) burns which are likely to have been life-threatening. The fact that the \%COHb levels are relatively low also indicates that the victims were overcome relatively quickly, before they had time to inhale large doses of toxic smoke. For fatalities with carboxyhaemoglobin levels above $40 \% \mathrm{COHb}$ an increasing proportion were recorded as having no burns at all, or only minor burns. It can be concluded that this group of fatalities were not intimate with the fire (so did not sustain burns) and were therefore in a location remote from the fire, most likely in a different room beyond the fire room, but in areas of the building filled with dense smoke containing high concentrations of CO and other gases. This group, comprising approximately $30 \%$ of fatalities, was therefore incapacitated and then died, mostly at the fire scene, as a result of exposure to toxic smoke.

Taking the first two groups with up to $20 \% \mathrm{COHb}$ (34\% of cases), these almost all suffered very severe burns within a short exposure period and inhaled relatively little smoke. It is therefore likely that this group were mostly intimate with the fire (for example ignited their clothing), and therefore died mostly due to burns. The next two groups (20-30\% and 30$40 \% \mathrm{COHb}$ ), obviously suffered longer exposures sufficient to obtain significant \%COHb levels, but also suffered very severe burns. From other published studies of smoke deaths and CO poisoning [21,30,31], while $\mathrm{CO}, \mathrm{HCN}$ and irritant smoke may have contributed to 
incapacitation and impairment of escape capability, it is considered unlikely that the majority of these deaths were due to smoke inhalation. The most likely scenario is that these victims were in the room of fire origin for up to around 15 minutes, but not intimate with the flames, and suffered a combination of incapacitating exposure to toxic smoke and burns, from exposure to heat radiation from the fire and hot upper layer, and heat convection from being enveloped in hot smoke. For these groups, although burns may have been important as an ultimate cause of death, it is likely that exposure to irritant and asphxyiant smoke, containing a variety of toxic gases, was a major cause of incapacitation and failure to escape, so that they remained in the fire until conditions became fatal.

For the $>40 \% \mathrm{COHb}$ exposure groups, the main cause of both incapacitation and subsequent death is considered to have been exposure to $\mathrm{CO}$ and other toxic gases. All these subjects have been exposed to toxic smoke for an extended period at a high concentration sufficient for them to have achieved very high \%COHb levels. Of these $48 \%$ have no or minor burns, so died from smoke exposure, so most were likely not to have been in the room of fire origin. The other $51 \%$ have severe burns, but it is likely that many of these were post-mortem burns, since these fatalities all survived long enough to suffer fatal CO exposure. As with the other groups, these subjects will have been incapacitated by exposure to toxic smoke a few minutes before death from asphyxia and then, in half the cases, post-mortem burns due to subsequent fire spread.

On the basis of this analysis it is considered that exposure to toxic smoke is likely to have been a major cause of incapacitation and subsequent death in approximately $70-80 \%$ of all these fatalities.

An interesting observation with regard to burns is that by far the majority of fatalities either had no burns or very severe burns over large areas. Only $12 \%$ of fatalities had minor burns. These were mostly in the high \%COHb groups, so may have been post-mortem burns. 


\section{DISCUSSION}

\section{Comparison between incidence of deaths and injuries in Poland and other countries}

Analysis of fire statistics data sets is always challenging because of the necessary simplification of data from specific incidents, and comparisons with those from different countries is difficult due to difference in methods of data collection and reporting, differences in building styles and building contents and differences in cultures and life styles.

The comparison in Figure 1 between Polish and UK death and injuries highlights some important aspects. The data from the UK date from the immediate post WWII austerity period. During this period upholstered furniture in the average home was somewhat limited and constructed mainly from traditional materials, such as cotton covers over coconut fibre and steel spring fillings on a wood frame. Fires involving such furniture tended to be slow growing and produced limited smoke, so that as shown in Figure 1, very few occupants were overcome by toxic smoke, while most deaths and injuries resulted from burns where victims were intimate with the fire. The situation changed dramatically from the 1970s, when most modern synthetic materials became widely used, and there was a large increase in deaths peaking at around 18/million population and injuries peaking at around 200/million mostly resulting from exposure to toxic smoke and fire gases. In the UK an equally dramatic improvement followed the introduction of the furniture flammability regulations in 1988 coupled with the increasing use of domestic smoke detectors in the early 1990s.

The current situation in Poland is that the incidence of deaths is similar to that in the UK during the 1970s and 1980s, and approximately three times that currently in the UK, while the 
incidence of injuries is approximately double those in the UK. There may be a number of contributory factors to these differences, including life-style and cultural differences, less publicity and awareness about fire hazards in the home, and lower installation rates for smoke alarms, but the particular UK requirements for furniture flammability may well be significant.

From the fire case reports analysed for this study, typical fatal fire scenarios in Poland appear to be similar to those in the UK. In this context it is important to distinguish between serious but non-fatal fire scenarios and fatal fire scenarios. In a detailed study of 100 non-fatal domestic fires in the UK [32], it was found that by far the main cause of serious domestic fires (resulting in fire service attendance and significant smoke exposure), was kitchen fires and electrical fires involving domestic appliances. Whereas in a recent study of fatal fires in Northern Ireland, "smokers materials", basically "careless" use of small ignition sources such as cigarettes, showed as the major cause, and typical cases involved adult persons living alone, mostly men, and significant alcohol intake [33]. This is similar to the pattern showing Poland, with $70 \%$ male fatalities, a high proportion living alone, and with a high incidence of alcohol. As in the UK most of these are dwelling fires, involve furniture, with the victim overcome either in the fire room or beyond the room of origin.

\section{Causes of incapacitation and death}

The two main causes of injury and death in fires are exposure to toxic smoke and burns. From the fire statistics it is difficult to determine the effects of exposure to optically dense, irritant smoke on escape in fire fatalities, but it is clear from detailed incident investigations and interviews with fire survivors, that occupants may become trapped or their escape fatally delayed by exposure to dense smoke. Since furniture fires have been shown to produce dense 
smoke very quickly following ignition, this is certainly a factor in the failure of some fatal victims to escape.

In order to determine the effects of burns and asphyxiant gases as causes of incapacitation and death, the \%COHB level is an important parameter, because it provides a measure of the both the duration of exposure during a fire and the total dose of both $\mathrm{CO}$ and other toxic gases to which the victim has been exposed. Where subjects have died with very low \%COHb levels (< $10-20 \% \mathrm{COHb}$ ) and have severe burns (30\% if cases), it is likely that they were intimate with the flames and that smoke and toxic gases were less of a factor.

Where \%COHb levels exceed approximately 20\%COHb, then subjects have been exposed long enough to inhale significant quantities of asphyxiant gases. A set of issues is then the extent to which CO and/or other asphyxiant gases caused incapacitation and prevented escape, and the extent to which other asphyxiant gases in addition to CO contributed or were the ultimate cause of death. In this context care is necessary when interpreting the \%COHb data. In this data set there are is a significant proportion of cases in the $20-40 \% \mathrm{COHb}$ range. The majority of these have severe burns, which is likely to have been the main cause of death, but it is likely that asphyxia and syncope from exposure to $\mathrm{HCN}$ and $\mathrm{CO}$ may have been a factor in causing incapacitation. A proportion, particularly in the $40-50 \% \mathrm{COHb}$ range were unburned, so must have been overcome and then died from exposure to asphyxiant gases. Since exposure to CO alone can cause collapse above $30 \% \mathrm{COHb}$, it is likely that subjects in this range had inhaled sufficient CO to cause incapacitation (syncope), but many of them may have already collapsed due to HCN inhalation before they inhaled sufficient CO to cause incapacitation. With regard to the relative lethality of $\mathrm{CO}$ alone and smoke mixtures containing both $\mathrm{CO}$ and other gases, the work of Nelson is especially relevant [see 30]. It is important to remember that asphyxia fatalities continue to inhale $\mathrm{CO}$ and other gases until the point of death, which is beyond the 
"fatal" dose from which they could be saved if treated. Thus for simple CO gas inhalation fatalities, only $15 \%$ are found with $<50 \% \mathrm{COHb}$ in their blood, while the average level in a fire fatality is around $70-80 \% \mathrm{COHb}$ [30]. This contrasts with non-burned fire deaths, for whom around $30 \%$ have $<50 \% \mathrm{COHb}$, and the average level in a fatality is $50-60 \% \mathrm{COHb}$. Figure 8 compares the distribution of \%COHb levels in the Polish fire fatality data set with Nelson's distribution for non-fire deaths from CO gas poisoning [34]. .

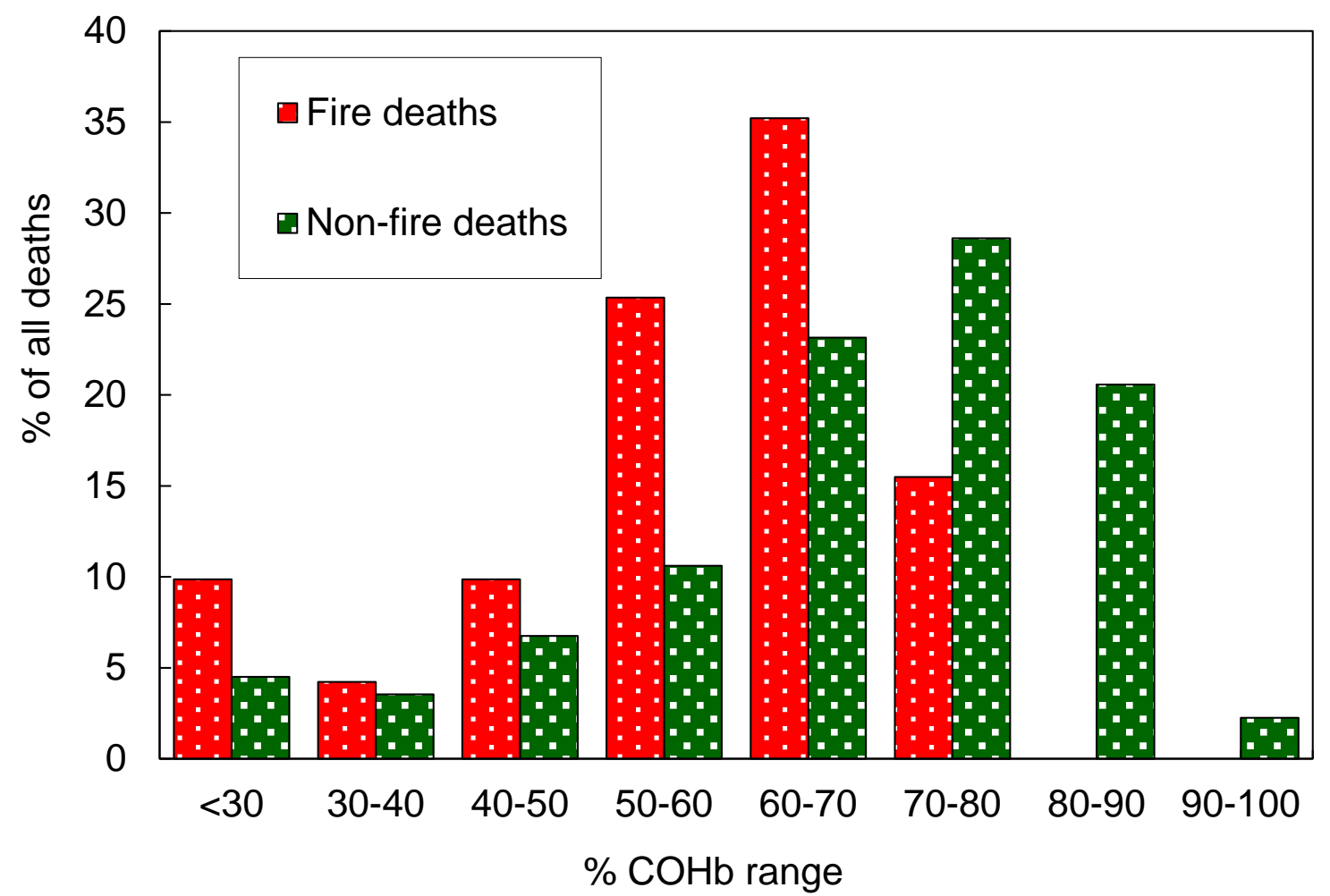

Figure 8 Frequency distribution of \%COHb levels in Polish fire fatalities without severe burns compared with Nelson's data for non-fire CO poisoning cases [34].

This demonstrates that for non-burned fire fatalities above $40 \% \mathrm{COHb}$, some other toxic product in addition to CO has made a significant contribution to both incapacitation and death. It is likely that HCN is an important contributor to these deaths. For the proportion of fatalities in the Polish data above $50 \% \mathrm{COHb}$, the main cause of both incapacitation and death is 
considered to have been asphyxiant gases. For those in the $60 \% \mathrm{COHb}+$ ranges, it is likely that $\mathrm{CO}$ is the main cause of death, although it is likely that HCN contributed to incapacitation in a proportion of cases.

\section{CONCLUSIONS}

Findings from 263 dwelling fire death cases over the period 2003-2011 in Mazowieckie region (mainly Warsaw area) have been reported. The incidence of fatal fires is approximately three times that in the United Kingdom. As in the UK the major cause of fatal fires was “carelessness” related to various ignition sources and cigarettes, with electrical fires as the next most common cause. Cases typically involved men (70\%) of whom $70 \%$ had consumed alcohol, with an increased risk for those living alone.

The majority (around 60\%) were in the room of origin, of whom around half were found close to burned upholstered furniture.

By far the majority of victims (>65\%) had inhaled sufficient smoke, CO and other gases to cause incapacitation and $80 \%$ were reported as having soot in their airways. Approximately $60 \%$ had inhaled sufficient CO, smoke and other gases to have contributed to or been the main cause of death. The non-burn deaths, showed an approximately 36\% excess over those predicted from $\mathrm{CO}$ poisoning alone, indicating a significant contribution to death from gases other than CO, over and above the contribution of these gases to incapacitation leading to death from other causes.

\section{REFERENCES}

[1] Stull, J.O., U.S. Fire Administration Firefighter Autopsy Protocol, the Federal Emergency Management Agency (FEMA), March 2008.

[2] Purser, D.A., Combustion toxicity. Chapter 62 pp, 2207-2307. SFPE Handbook of fire protection engineering 5th Edition. Hurley, M. et al Eds. Springer 2016. https://doi.org/10.1007/978-1-4939-2565-0_62

[3] Purser, D.A. and McAllister, J.L., Assessment of hazards to occupants from smoke, toxic gases and heat. Chapter 63 pp. 2308-2428.. SFPE Handbook of fire protection 
engineering $5^{\text {th }}$ Edition, Hurley M. et al. Eds. Springer-Verlag, New York. 2016. https://doi.org/10.1007/978-1-4939-2565-0_63

[4] Einhorn, I.N. Grunnet, M.L., Physiological and toxicological aspects of combustion of natural and synthetic materials: Past, present and future, Fire Safety Journal, 1, pp. 143169, 1978. https://doi.org/10.1016/0379-7112(78)90002-4

[5] Demiling, R.H., Smoke inhalation lung injury: an update, Eplasty, 8, e27, 2008.

[6] Fire Statistics United Kingdom; Department for Communities and Local Government: London, 2016.

http://www.communities.gov.uk/fire/researchandstatistics/firestatistics/firestatisticsuk/

[7] Purser, D.A. and Maynard, R.L., Chapter 1 Overview of combustion Toxicology. In: Toxicology survival and health hazards of combustion products. Editors: David A. Purser, Robert L. Maynard, James C. Wakefield. Royal Society of Chemistry (2016).

[8] Polish Fire statistics, http://www.straz.gov.pl/panstwowa_straz_pozarna/2011, 2016

[9] Gann, R.G., Averill, J.D., Butler, K.M., Jones, W.W., Mulholland G.W., Neviaser, J.L., Ohlemiller, T.J., Peacock, R.D., Reneke, P.A., Hall Jr. J.R., International study of the sublethal effects of fire smoke on survivability and health (SEFS): Phase 1. Final Report, NIST TN 1439, NIST Technical Note 1439, August 2001.

[10] Crewe, R.J., Stec, A.A., Walker, R., Shaw, J., Hull, T.R., Rhodes, J., Garcia-Sorribes, T., Experimental results of a residential house fire test on tenability: temperature, smoke, and gas analyses, Journal of Forensic Sciences, 59(1), pp. 139-154, 2014. https://doi.org/10.1111/1556-4029.12268

[11] Purser, D.A., Chapter 2, Fire types and combustion products. In: Toxicology survival and health hazards of combustion products. Editors: David A. Purser, Robert L. Maynard, James C. Wakefield. Royal Society of Chemistry (2016).

[12] Stec, A.A., Hull, T.R., Fire Toxicity, Cambridge, Woodhead Publishing, CRC Press, 2010

[13] Stec, A.A., Hull, T.R., Lebek, K., Purser, J.A., Purser, D.A., The effect of temperature and ventilation condition on the toxic product yields from burning polymers, Fire and Materials, 32, pp. 49-60, 2008. https://doi.org/10.1002/fam.955

[14] Hull, T.R., Stec, A.A., Lebek, K., Price, D., Factors affecting the combustion toxicity of polymeric materials, Polymer Degradation and Stability, 92, pp. 2239-2246, 2007. https://doi.org/10.1016/j.polymdegradstab.2007.03.032

[15] Stec, A.A., Hull, T.R., Assessment of the fire toxicity of building insulation materials, Energy and Buildings, 43, Issues 2-3, pp. 498-506, 2011. https://doi.org/10.1016/j.enbuild.2010.10.015

[16] Hull, T.R., Brein, D., Stec, A.A., Quantification of toxic hazard from fires in buildings, Journal of Building Engineering, Available online 27 February 2016, https://doi.org/10.1016/j.jobe.2016.02.014

[17] Purser, D.A. (2014) Fire safety performance of flame retardants compared with toxic and environmental hazards. In: Polymer Green Flame Retardants. Eds. Constantine D. Papaspyrides and Pantelis Kiliaris. Chapter 2 pp. 45-86. Elsevier, Oxford 2014.

[18] Levin, B.C., Kuligowski, E.D., Toxicology of fire and smoke, Inhalation Toxicology, $2^{\text {nd }}$ Edition, Chapter 10, CRC Press (Taylor and Francis Group), Boca Raton, FL, Salem, H.; Katz, S. A., Editor(s), pp. 205-228, 2005.

[19] Purser, D.A., Behavioural impairment in smoke environments, Toxicology, 115, pp. 2540, 1996. https://doi.org/10.1016/s0300-483x(96)03493-2

[20] ATSDR, Agency for Toxic Substances and Disease Registry, Toxicological Profile for Carbon Monoxide. Department of Health and Human Services, Public Health Services, 2012 
[21] Purser, D.A., Chapter 4. Asphyxiant components of fire effluents, In Fire toxicity. Eds A.Stec and R. Hull. 2010, pp 118-198 CambridgeWoodhead Publishing LTS

[22] Chaturvedi, A.K., Sanders, D.C., Endecott, B.R., Ritter, R.M., Exposures to carbon monoxide, hydrogen cyanide and their mixtures: interrelationship between gas exposure concentration, time to incapacitation, carboxyhemoglobin and blood cyanide in rats, J. Appl. Toxicol., 15, pp. 357-363, 1995. https://doi.org/10.1002/jat.2550150504

[23] Hartzell, G.E., Overview of combustion toxicology, Toxicology, 115, pp. 7-23, 1996. https://doi.org/10.1016/s0300-483x(96)03492-0

[24] Lindsay, A.E., Greenbaum, A.R., O’Hare, D., Review Analytical techniques for cyanide in blood and published blood cyanide concentrations from healthy subjects and fire victims, Analytica Chimica Acta, 511, pp. 185-195, 2004. https://doi.org/10.1016/j.aca.2004.02.006

[25] Nelson, L., Acute cyanide toxicity: Mechanisms and manifestations, Journal of Emergency Nursing, 32, pp. S8-S11, 2006. https://doi.org/10.1016/j.jen.2006.05.012

[26] Hartzell, G.E., Advances in combustion toxicology, CRC Press; 1st Edition, Vol 1, Chapter 3, pp. 25-28, 1989.

[27] Purser, D.A., Toxicity assessment of combustion products and modeling of toxic and thermal hazards in fire. Effects of fire in combustion products. SFPE handbook of Fire Protection Engineering. National Fire Protection Association, Quincy, MA, Section 1, pp. 200-245, 1988.

[28] Anderson, R.A., Thomson I., Harland, W.A., The importance of cyanide and organic nitriles in fire fatalities, Fire Materials, pp. 191-199, 1979. https://doi.org/10.1002/fam.810030207

[29] Lundquist, P., Rammer, L., Sörbo, B., The role of hydrogen cyanide and carbon monoxide in fire casualties: a prospective study, Forensic Sci Int., 43, pp. 9-14, Sep. 1989. https://doi.org/10.1016/0379-0738(89)90116-3

[30] Purser, D.A., Effects of pre-fire age and health status on vulnerability to incapacitation and death from exposure to carbon monoxide and smoke irritants in rosepark fire incident victims. In Press Fire and Materials 2016

[31] Pach, J., Cholewa, L., Marek, Z., Bogusz, M., Groszek, B., Analysis of Predictive Factors in Acute Carbon Monoxide Poisonings. Folia Medica Cracoviensia, 20, pp. 159-168, 1978.

[32] Purser, D.A., Kuipers, M., Interactions between buildings, fire and occupant behaviour using a relational database created from incident investigations and interviews. $3^{\text {rd }}$ International Symposium on Human Behaviour in Fire. Europa Hotel, Belfast, 1-3rd September 2004. Proceedings pp. 443-456 Interscience Communications, London UK, 2004.

[33] Harpur, A., A detailed investigation into occupant behaviours and influencing factors surrounding fatal dwelling fire incidents in Northern Ireland. Ph.D Thesis February 2014. University of Ulster.

[34] Nelson, G.L., Carbon Monoxide and Fire Toxicity: a Review and Analysis of Recent Work. Fire Technol. 34, pp. 39-57, 1998. DOI: 10.1023/A:1015308915032 